\title{
What Determines Foreign Policy in Latin America? Systemic versus Domestic Factors in Argentina, Brazil, and Mexico, 1946-2008
}

\author{
Octavio Amorim Neto \\ Andrés Malamud
}

\begin{abstract}
Is it domestic politics or the international system that more decisively influences foreign policy? This article focuses on Latin America's three largest powers to identify patterns and compare outcomes in their relations with the regional hegemon, the United States. Through a statistical analysis of voting behavior in the UN General Assembly, we examine systemic variables (both realist and liberal) and domestic variables (institutional, ideological, and bureaucratic) to determine their relative weights between 1946 and 2008. The study includes 4,900 votes, the tabulation of 1,500 ministers according to their ideological persuasion, all annual trade entries, and an assessment of the political strength of presidents, cabinets, and parties per year. The findings show that while Argentina's voting behavior has been determined mostly by domestic factors and Mexico's by realist systemic ones, Brazil's has a more complex blend of determinants, but also with a prevalence of realist systemic variables.
\end{abstract}

$\mathrm{T}$ he emergence of left-leaning governments throughout Latin America, the socalled Pink Tide, has become conspicuous in recent years. As a consequence of the pervading ideology of the new administrations, "one would expect a more assertive approach to foreign policy" (Gardini and Lambert 2011, 1). This scenario provides a good opportunity to perform a test: to evaluate the relative weights of systemic and domestic variables. Since the United States has been traditionally the antimodel and antagonist for the Latin American left-as much as a reference and ally for the right — we posit that focusing on a country's alignment with the United States is a proper way to gauge the impact of ideology and related domestic factors, such as regime type, on foreign policy. From a more general perspective, this strategy can inform us as to whether it is systemic or domestic forces that have more decisively influenced Latin American foreign policy.

Octavio Amorim Neto is an associate professor at the Brazilian School of Public and Business Administration (EBAPE), Getúlio Vargas Foundation. oamorim@fgv.br. Andrés Malamud is a senior research fellow at the Institute of Social Sciences, University of Lisbon. amalamud@ics.ul.pt 
We set as our goal to study the distribution of capabilities, the degree of trade interdependence, and the government profile of the three regional giants (i.e., Argentina, Brazil, and Mexico) over a large stretch of time (1946-2008) to identify the factors that best predict their alignment with the United States.

Our dependent variable is operationalized by a quantitative indicator and measured by voting convergence on United Nations General Assembly resolutions. Using voting convergence as a proxy for policy alignment with the United States follows a mainstream methodological choice (Lima and Hirst 2006; Mares 1988a; Covarrubias 2003). Our independent variables are divided into systemic and domestic. The focus of the former is the distribution of capabilities, the strategic priority of the regional hegemon, and the degree of trade interdependence. As concerns domestic variables, centrality is given to political attributes and government orientation: the presence of democracy as measured by the role of the military and strength of the left, executive's and legislature's ideological persuasion, and magnitude of political support.

The article proceeds to review the relevant literature and flesh out the main hypotheses. It then discusses the significance of using votes taken at the UN General Assembly. It advocates the use of two operational indicators of systemic factors; namely, the Composite Index of National Material Capabilities (CINC) and trade dependence on the United States. Country-specific measures of domestic politics are provided before the hypotheses are tested using time-series analysis. The findings of this study indicate that while Argentina's alignment with the United States has been determined mostly by domestic factors and Mexico's by realist systemic factors, Brazil's international behavior has a more complex blend of determinants, but also with a prevalence of realist systemic variables.

\section{Foreign Policy AND ITS DETERMINANTS}

Domestic and international politics are usually approached as separate domains, both ontologically and epistemologically. Accordingly, political science has developed two distinct subdisciplines to deal with phenomena taking place either within the state (comparative politics) or between states (international relations). Whereas hierarchy and the monopoly of violence characterize the former, anarchy and changing configurations of power distinguish the latter. Foreign policy constitutes an intersection area, as it is both a public policy developed from within the state and the main input of international politics. In the field of international relations, neoclassical realism is the theory that best grasps the interactions between domestic political explanations of a state's foreign policy choices and systemic or structural (i.e., international) explanations (Rose 1998; Lobell et al. 2009).

Neoclassical realism holds that the actions of a state in the international system can be explained by a combination of systemic variables (such as the distribution of capabilities among states), cognitive variables (such as the perception and misperception of systemic pressures, other states' intentions, and threats), and domestic 
variables (such as state institutions, elites, and social actors) affecting the power and freedom of action of decisionmakers. While holding true to the neorealist concept of balance of power, neoclassical realism adds that states' mistrust and inability to perceive one another accurately, or state leaders' inability to mobilize state power and public support, can result in an underexpansion or underbalancing behavior leading to imbalances within the international system, the rise and fall of great powers, and war (Schweller 2004; Zakaria 1998).

The primary motivation underlying the development of neoclassical realism was that structural realism, while useful to explain systemic outcomes, had little to offer about particular states' (unexpected) behavior. In its own words, structural realism offered a theory of international politics, not foreign policy, that impaired the understanding of agency and change. The innovation of neoclassical realism consisted of adding domestic variables between systemic incentives and foreign policy decisions. Its basic theoretical architecture contemplates the distribution of power in the international system as an independent variable, the domestic perception of the system and domestic incentives as intervening variables, and foreign policy decisions as dependent variables.

Foreign policy is an area relatively prone for words to diverge from deeds, given its aloofness from public scrutiny, its relatively weak dependence on bills of law approved by the legislature, and the little direct impact it has on citizens' daily lives-especially in countries that are international lightweights. Therefore, the expectation that foreign policy be internally coherent is contingent on the case in point, as foreign policy may express political struggles and organizational traditions (Allison 1971) or even leaders' personal moods rather than rational planning. The international politics of Latin America, usually far from the centers of high politics, constitutes a laboratory fit to analyze the degree to which foreign policy can be subordinated to domestic struggles.

Drawing on rival theories of international relations and foreign policy, we advance the following propositions about the determinants of Latin American alignment with the United States:

P1. The larger a country's national capabilities (as a percentage of total world capabilities), the lower its voting convergence with the United States.

The rationale underlying this proposition is that in the Latin American context, larger capabilities help countries to loosen the stranglehold the United States has on their international behavior. As greater power carries greater responsibilities and risks, it might demand a tighter foreign policy adjustment to structural determinants. This is likely to be translated into some kind of soft balancing with the United States; for example, not following Washington's lead on UN motions. While aligning with the United States can pay off in the short run, higher degrees of autonomy might be desirable in the long run. Such autonomy is more feasible when national capabilities grow. ${ }^{1}$ 
P2. The heavier the trade dependence on the United States, the higher the voting convergence.

The rationale is that a heavier trade dependence on the largest international economy and regional hegemon requires a better adjustment in the conduct of foreign policy to structural determinants.

P3. Convergence with the United States should be higher during the Cold War period (1946-1989) than afterward (1990-2008).

It is plausible to argue that regional hegemons demand tighter alignments when they face competition within their sphere of influence, and especially within their security perimeter. In the U.S. case, this was true even before the Cold War, as the Monroe Doctrine explicitly called for the exclusion of extracontinental powers from the Western Hemisphere. Our intuition is that the implosion of the Soviet Union and the end of the Cold War could have relaxed U.S. pressures for alignment, thus allowing Latin American states more leeway in foreign policy and reducing their voting convergence with the United States.

P4. The stronger the military in the political system, the higher the voting convergence.

Given the traditional conservatism and staunch anticommunism of the Latin American military and its professional ties with its U.S. counterpart, the larger the role of the military in domestic politics, the higher the probability of diplomatic cooperation with the United States. Communist Cuba and Bolivarian Venezuela are certainly exceptions to this rule.

\section{P5. The more leftist the government makeup, the lower the voting convergence.}

Given the ponderous presence of the United States in Latin America, left-wing political forces are the ones that have the most intense preferences for changing the status quo in foreign policy. This may lead to intense reactions by their right-wing opponents. Moreover, among all public policy areas, foreign policy is the one that most easily can be changed by means of symbolic gestures and official pronouncements by the chief executive and the foreign minister. So a Latin America country with strong left-wing political forces is likely to see the conduct of its foreign policy affected by domestic factors.

P6. Overall, the magnitude of the president's political support has no significant impact as a determinant of convergence with the United States.

Here the rationale is that a politically stronger president may more easily change foreign policy according to his or her preferences. However, a politically weak president will also have incentives to use foreign policy to generate political capital, given that foreign policy is easy to change, as per the rationale of P5. There- 
fore, in the short term, we foresee some changes in foreign policy as a function of the president's magnitude of political support, but in the long run, weak and strong presidents will cancel the effect of each other.

Our task now is to test these propositions. We have selected three cases that combine geopolitical relevance with political diversity, as they share some structural commonalities while offering variation in the independent variables. On the one hand, Argentina, Brazil, and Mexico are traditionally considered the largest Latin American powers and are all characterized by presidentialist executives. On the other hand, their geographic proximity and trade interdependence with the United States range across the full spectrum. The political power of the military ranges from high in Argentina and Brazil in the 1970s through middle in Brazil in the 1980s to consistently moderate to low in Mexico. The ideological makeup of their administrations has varied widely, both within each country and across countries, short of communism. Therefore they constitute a relevant and variegated sample to test the influence of systemic and domestic factors on voting convergence with the United States.

\section{UN General Assembly Votes as a Proxy for Foreign Policy}

We aim to generate insights into Argentina's, Brazil's, and Mexico's foreign policy by looking at how they voted on UN General Assembly motions. ${ }^{2}$ The choice of this measure, however, is not consensual, as some analysts see the General Assembly only as a passive arena as regards the interaction of states (Dixon 1981) or consider the votes recorded therein as merely symbolic (Kennedy 2006, 34). Other authors make use of these votes to identify the position of countries on multilateral issues and regional alignments (Lijphart 1963; Marín-Bosch 1998; Selcher 1978). However, a strand of the scholarly literature treats these votes as an indicator of the general orientation of states' foreign policy (Thacker 1999; Tomlin 1985; Voeten 2000). We draw on this strand to justify our operational decisions.

Tomlin (1985) examines the validity of indicators that rely on votes cast in the UN General Assembly. He asks whether and to what extent the similarity among these votes can be used to describe interstate relations in the broader arena of international politics. The answer is based on the analysis of the behavior of black African states in the 1960s, both in the UN General Assembly and in the African subsystem. Tomlin argues that UN votes are relevant only if they are consistent with the behavior observed in the African subsystem - that is, outside the UN—and concludes that UN voting patterns are a valid indicator of states' attitudes toward the rivalry between the superpowers of the Cold War. Particularly important for the purposes of this article is the strong correlation found between the votes cast in the UN General Assembly and the foreign policy of African countries regarding the United States. Thus, UN voting behavior provides a valid indicator of national alignment with the United States (Tomlin 1985, 205-6).

Voeten (2000), in turn, investigates the validity of a number of theoretical contributions to the study of international relations through the analysis of votes cast in 
the UN General Assembly, both in the Cold War period (1946-88) and later (199196). He argues that this kind of study can reveal changes in states' behavior as well as demonstrate the dimensionality of global conflicts (Voeten 2000, 185-86).

But is there any palpable consequence of votes cast in the UN General Assembly? Thacker (1999) categorically states that yes, there is: ceteris paribus, the more a state moved toward the U.S. position in the votes taken in the General Assembly, the greater the likelihood of its receiving International Monetary Fund loans between 1985 and 1994.

In short, voting in the UN General Assembly both reflects international alignment and entails political consequences. Following on the works of Thacker, Tomlin, and Voeten, we analyze the votes cast on UN General Assembly motions by Argentina, Brazil, and Mexico from 1946 to 2008 and the degree of convergence of each of these countries with the United States. For this, we use the database built by Erik Voeten and Adis Merdzanovic, "United Nations General Assembly Voting Data" (2008), which has a record of all roll-call votes on which there was no unanimity.

\section{The Calculus of Convergence}

There are two methods to compute the convergence between two countries on votes held in the UN: simple convergence and Lijphart's Index of Agreement (1963). Simple convergence calculates the percentage of identical votes cast by two countries (yes/yes, no/no, or abstain/abstain). Lijphart's Index of Agreement takes into account not only identical votes but also those on which states converge partially (yes/abstain and no/abstain). It was originally formulated to identify blocs within the United Nations.

Simple convergence has been criticized for not considering that situations in which one country votes yes or no and the other abstains do not necessarily constitute complete divergence. The main criticism leveled at the Index of Agreement is that if on 100 votes, country A abstains all times and country B only votes yes or no, $\mathrm{A}$ and $\mathrm{B}$ will have a convergence of 50 percent, the same convergence that is obtained if A never abstains and votes the same way as B 50 percent of the time.

Apart from the above reason, we opted for simple convergence because it has been adopted by U.S. diplomats (Thacker 1999) and their Latin American counterparts to evaluate each other's international behavior. For example, according to what one former foreign minister of Brazil says of another,

In justifying [Brazil's] independent foreign policy, Afonso Arinos ... says in his memoirs that the first goal of Quadros [Brazil's president in 1961], for whom he was foreign minister, "was to break with the Foreign Ministry's old tradition of always voting with our friends of the United States" (Lampreia 2010, 252).

Similarly, though in the opposite direction, Argentine foreign minister Guido Di Tella (1991-99) steered a pro-U.S. turn in his country's foreign policy by demanding that the Argentine ambassador to the UN reach a 60 percent voting coincidence with the United States if he wanted to keep his post (Escudé and Cis- 
Figure 1. Argentina's, Brazil's, and Mexico's Convergence with the United States in the UN General Assembly, 1946-2008

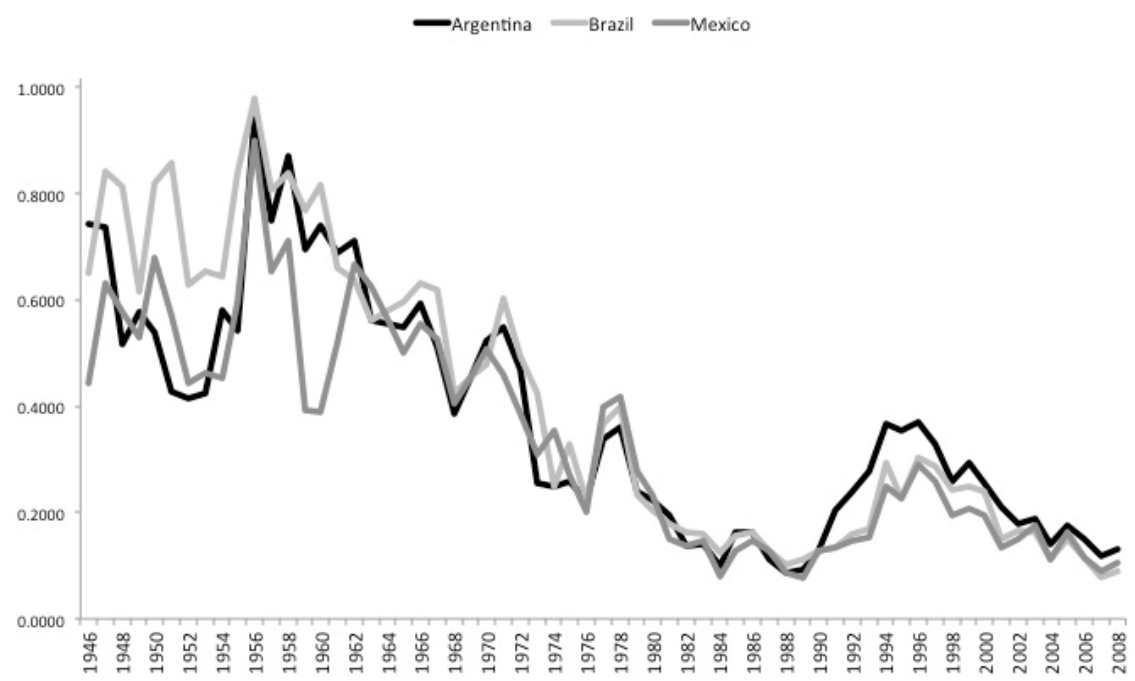

Source: Voeten and Merdzanovic 2008.

neros 2000, 15, 42-47). In turn, the importance that the U.S. government concedes to voting records at the UN General Assembly is manifest in the annual edition of the Report to Congress on Voting Practices in the United Nations, drafted by the Department of State (Thacker 1999).

What diplomats from Latin America and the United States take into account when examining UN General Assembly votes is precisely the degree of identity of their positions. That is to say, a simple measure of convergence is also intersubjectively valid, since it corresponds to the meaning attributed to it by the relevant players. Yet we will also use Lijphart's Index of Agreement to check the robustness of our findings.

Voeten and Merdzanovic's database has 4,900 voting records. Figure 1 displays the yearly convergence of Argentina, Brazil, and Mexico with the United States over the period 1946-2008. Note that the three curves display the same downward trend, with many similar peaks and valleys. However, there are important differences: Brazil displays a conspicuously higher convergence with the United States in the 1940s and 1950s than Argentina and Mexico; Argentina is more convergent with the United States in the 1990s than Brazil and Mexico; and Mexico is very far from both Argentina and Brazil in the late 1950s. Yet in the whole picture, similarities prevail over differences. This means that if we find different determinants of the foreign policy of the three countries, we have a case of equifinality. 
Figure 2. National Material Capabilities (CINC) of Argentina, Brazil, Mexico and the United States, 1946-2008

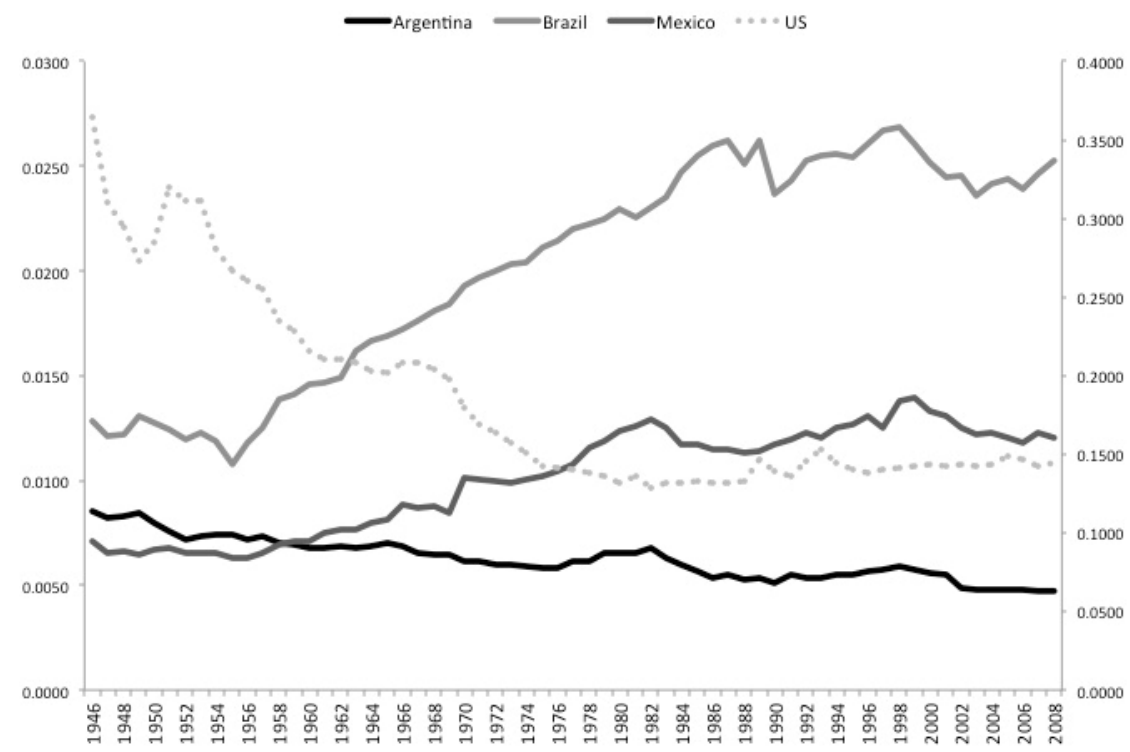

Note: The U.S. CINC is on the secondary axis.

Source: Singer et al. 1972.

\section{SySTEMIC VARIABLES}

We test three systemic variables: each country's position in the international hierarchy of military and economic power, its degree of asymmetric interdependence on the United States, and the strategic priority of the United States. The first variable is a tributary of neorealist theory and was measured by resorting to the Composite Index of National Capabilities (CINC), a statistical measure of national power that combines six different components representing demographic (total and urban population), economic (iron and steel production and energy consumption), and military (expenditure and personnel) strength (Singer et al. 1972). The second variable stems from liberal theories, and measures exports to the United States as a proxy for economic dependence; accordingly, we tabulated all annual trade entries for the period 1946-2008. The third variable relates to the intensity with which the United States sought to align the Western Hemisphere, and uses a binary variable (incidence of the Cold War) to gauge it. Figure 2 displays the national capabilities of Argentina, Brazil, Mexico, and the United States in the period 1946-2008. Figure 3 exhibits Argentina's, Brazil's, and Mexico's trade dependence on the United States. ${ }^{3}$ 
Figure 3. Exports to the United States as Percent of Total Exports of Argentina, Brazil, and Mexico, 1946-2008

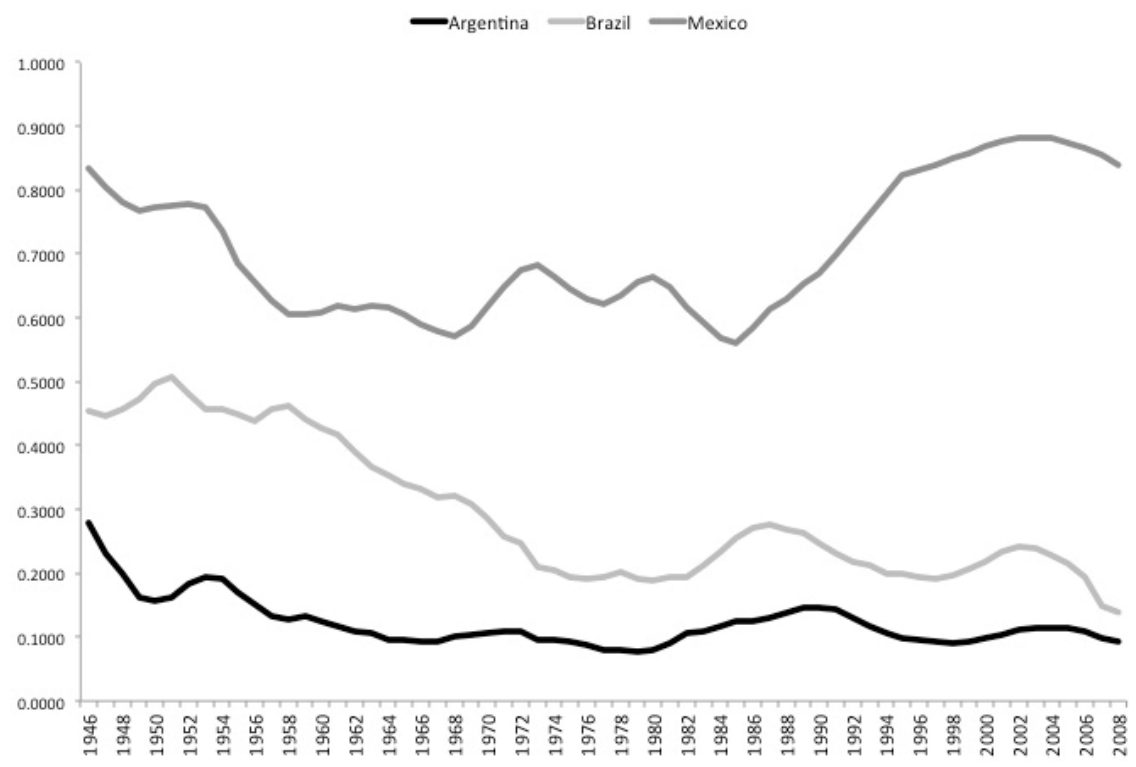

Sources: U.S. Census Bureau 1940-2012; Ministry of Development, Industry and Foreign Trade n.d. (for 1953-88); IBGE (for 1940-52); AliceWeb2 (for 1989-2008); Aparicio Cabrera 2011.

\section{COUNTRY-SPECIFIC Domestic Politics Variables}

Our domestic variables include a set of ideological and ideological-institutional measures, since in Latin America the left is traditionally associated with anti-Americanism: the president's ideology, the president's political strength, the cabinet's ideological leaning, the legislative strength of left and center-left parties, and the presence and weight of military ministers in the cabinet-which is associated with the ideological right (see figures 4-6). The latter variable is associated with the nature of the regime (i.e., democratic or not), but it also provides meaningful information about military influence in civilian administrations. With the assistance of country experts, we coded 1,500 ministers in 3 countries according to their ideological persuasion, as well as the political strength of presidents, cabinets, and parties per year. An overview of the national contexts framing and qualifying these variables follows. 
Figure 4. The Cabinet Strength of the Center-Left and of the Military in Argentina, 1946-2008

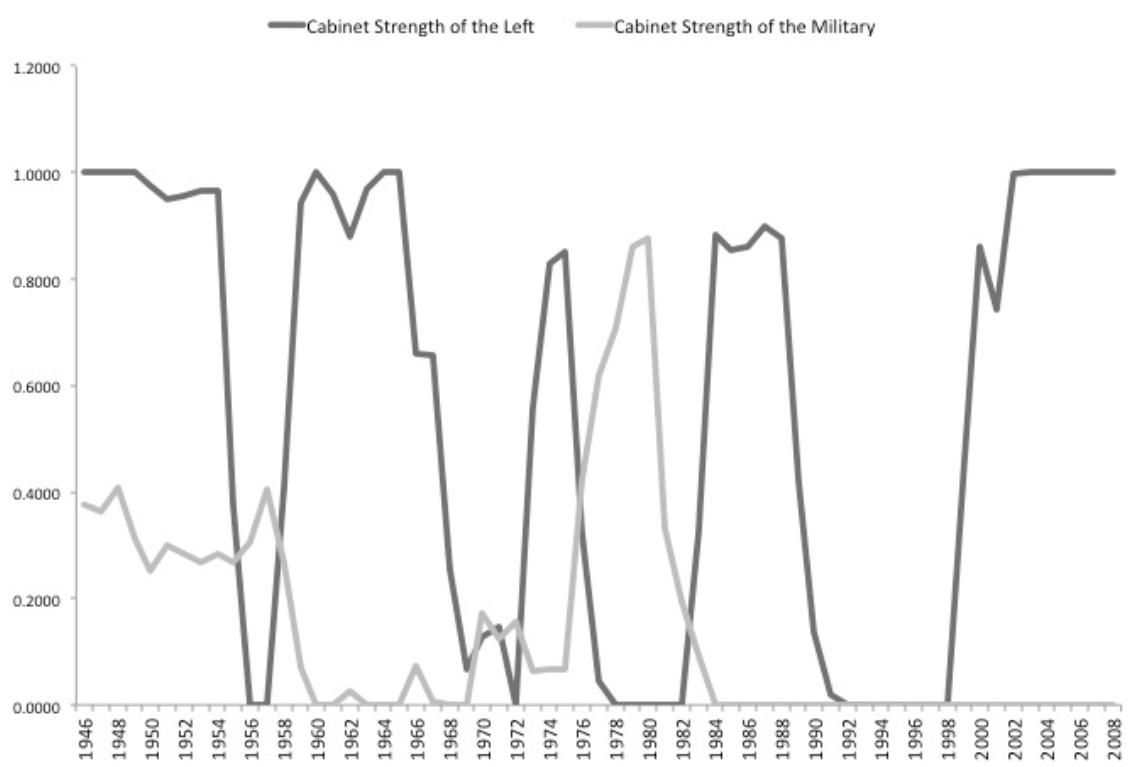

Note: The Argentine center-left is defined by its appeal to the popular sectors, not by any reference to doctrine.

Sources: Molinelli et al. 1999; data provided by Marcelo Camerlo and Miguel de Luca.

\section{Argentina}

Three organizations ruled over Argentina between 1946 and 2008: the Justicialista Party (PJ, Peronists), the Radical Civic Union (UCR, Radicals), and the armed forces. The Peronists won 9 presidential elections and held the presidential office for 32 years, whereas different branches of the Radical Party won in 4 opportunities and held the post for 16 years. For their part, 9 unelected military officers performed as chief executives in 17 years. Coalitions have been rare: although several presidents ran for office with a running mate from another party, single-party governments were vastly prevalent, and multiparty coalitions formed only twice: under Radical president Fernando De la Rúa (1999-2001) and Peronist caretaker Eduardo Duhalde (2001-3). As a consequence, most cabinets were ideologically coherent, the only significant exceptions being ephemeral Cámpora (1973) and caretaker Lastiri (1973), since they had to balance Peronist left and right wings.

The turbulent 1970s aside, the left-right ideology has not been a meaningful dimension of the Argentine party system (Catterberg and Braun 1989). Both the Peronists and the Radicals are catch-all parties. Although Peronism has a workingclass base and Radicalism is more representative of the middle classes, the two par- 
Figure 5. The Cabinet Strength of the Left, the Legislative Strength of the Left, and the Cabinet Strength of the Military in Brazil, 1946-2008

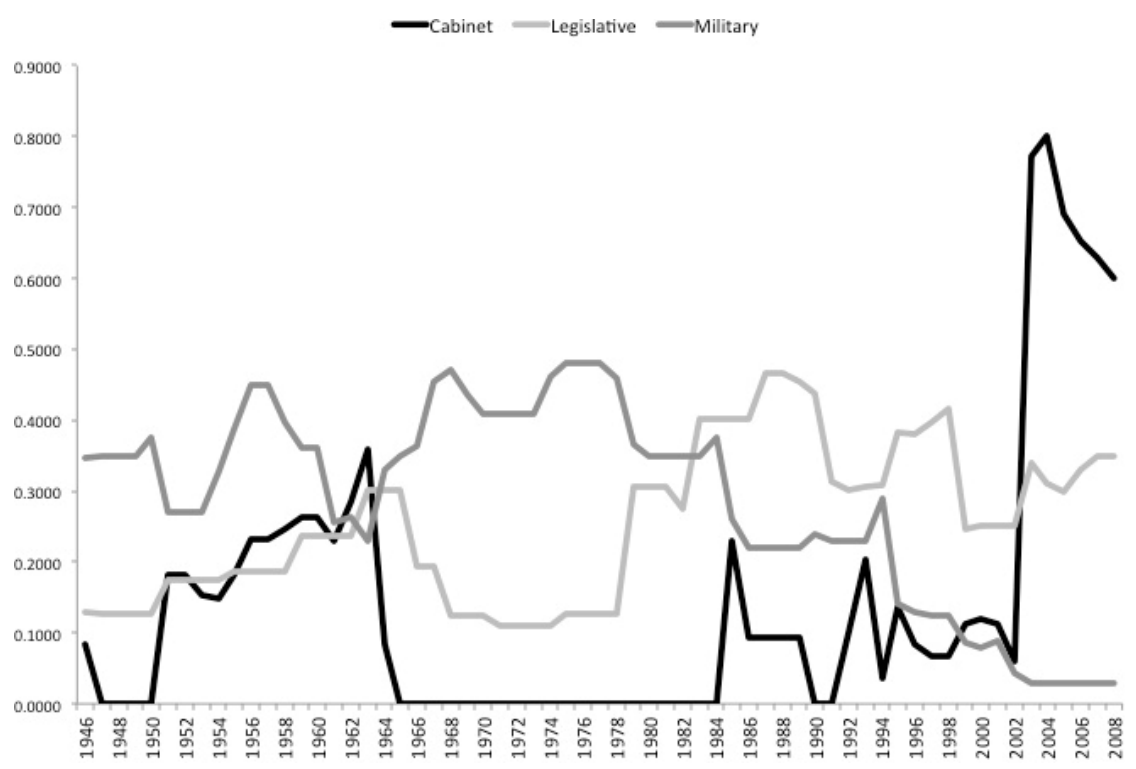

Source: Amorim Neto 2011.

ties have wings at both sides of the center, and neither can be labeled as consistently rightist or leftist. The main difference between them is that the ideological amplitude of Peronism is much wider: in some periods, extreme left and right factions coexisted — even killed each other- under the same party label. In contrast, the military can only be considered right-wing, even when it included dovish liberals and hawkish nationalists in the cabinet.

In our database we have classified most Peronist and Radical ministers as ideologically centrist, either because they belonged to a centrist party or because, when they were more ideologically laden, the president was the party leader and left no margin for manifestations of dissent. We gauged ideological positions at the time of appointment. Different values have been given in two cases: when ministers were independent or belonged to a token party (like Domingo Cavallo under Carlos Menem and De la Rúa) and when the president was not the party—or military—leader, as happened with Levingston (1970-71), Cámpora (1973), and De la Rúa (1999-2001).

In foreign policy, Argentina underwent three periods over the twentieth century. Before World War II, it followed three main orientations: "Europeanism, opposition to the United States, and isolation from the rest of Latin America" (Russell and Tokatlian 2006, 247; also Lanús 1986). The second period, between the end of World War II and the end of the Cold War, entailed nonalignment in regard to the United States without implying equidistance between the blocs; vowing Latin 
Figure 6. The Cabinet Strength of the Left and the Cabinet Strength of the Military in Mexico, 1946-2008

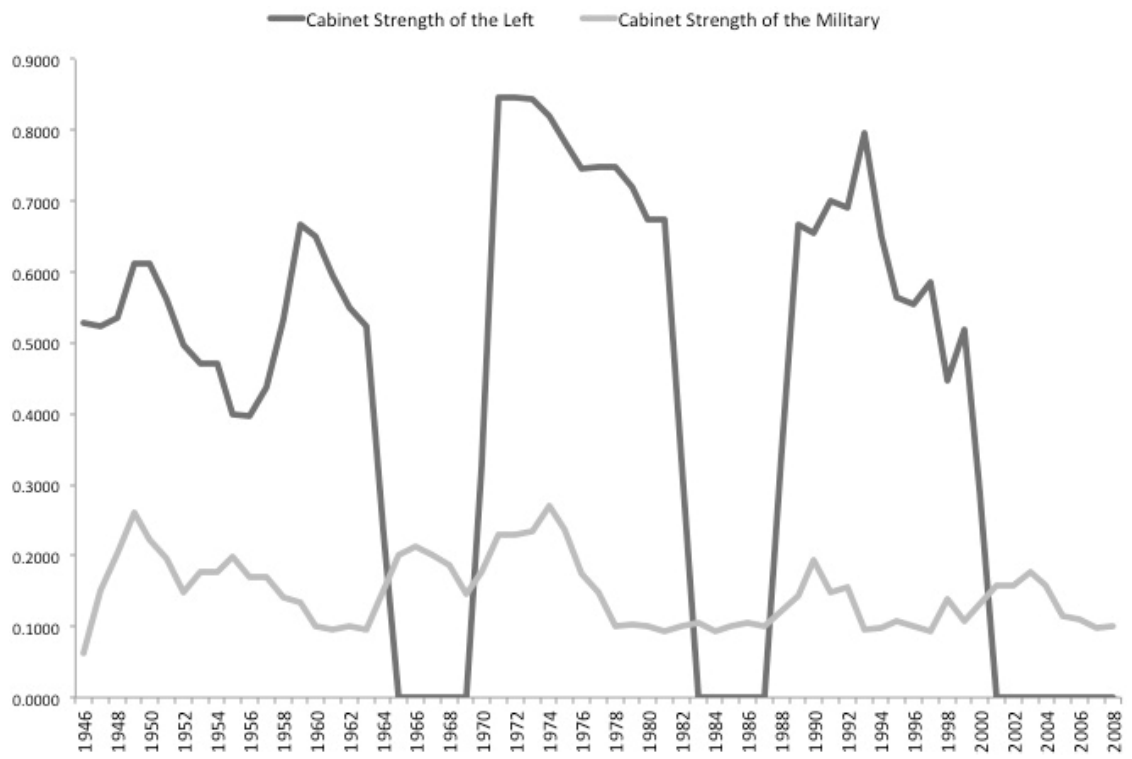

Sources: Camp 2011; Coppedge 1997; Craig and Cornelius 1995; Quijano Torres 2012; and a survey of experts responded to by Roderic Ai Camp, Alain De Remes, Todd Einsenstadt, Cecilia Martínez-Gallardo, and Antonio Ortiz-Mena.

American integration without doing much to deliver; rejecting international regimes that sought to freeze the distribution of world power; and diversification of commercial partnerships irrespective of ideology (Russell and Tokatlian 2006, 266). After the end of the Cold War, Peronist president Menem steered a foreign policy change. "Automatic alignment" or "pragmatic acquiescence" was premised on subordination to the political and strategic interests of the United States; the definition of national interests in economic terms; active participation in the creation and strengthening of international regimes in line with the Western countries and the Washington Consensus; and support for regional economic integration and unilateral openness (Russell and Tokatlian 2006, 267).

Once into the twenty-first century, the arrival of the Kirchners gave a new twist to an already twisted history (Malamud 2011). As Margheritis $(2010,1)$ explains, "apparently contradictory and inconsistent foreign policy behavior shaped Argentina's reputation as an erratic and relatively unpredictable international actor-the adjectives going, in fact, from pariah to wayward to unreliable partner." This behavior has included several turns, ranging from small adjustments to dramatic policy shifts. Remarkably, such a pattern has been due to policy inconsistencies not only between political parties but also within them, especially the PJ. 


\section{Brazil}

Between 1946 and 2008, Brazil had three political regimes: democracy from 1946 to 1964, military rule from 1964 to 1985, and democracy again since March 1985. Key institutional pillars remained largely untouched over these 63 years, including presidentialism (with the exception of a parliamentary interregnum in the years 1961-63), bicameralism, federalism, and the congressional electoral system. In contrast, throughout these decades, there were different party systems, wide swings in the degree of executive centralization, elections with varying degrees of freedom and fairness, and legislatures and courts with changing degrees of independence and influence.

A key feature of Brazil's political landscape since 1946 has been the so-called coalitional presidentialism (Abranches 1988; Amorim Neto 2006; Figueiredo 2008; Power 2010; Santos 2003). This is due to the absence of a presidential party that commands a legislative majority. In 1946-64, Brazil already had a moderately fragmented party system, and since 1990 the country has been electing the world's most fragmented legislatures. Therefore, chief executives are often hard pressed to offer cabinet posts to many parties in return for legislative support, a pattern relatively similar to what prime ministers do in parliamentary systems. This is to say, unlike their Argentine and Mexican counterparts, Brazilian presidents do not govern alone. The exception to this rule was obviously the military regime, during which the governing party (ARENA/PDS) enjoyed a legislative majority-except for 1983-84.

Executive-legislative relations have been fraught with grave conflicts and dire consequences: nearly all presidents who failed to build or maintain a legislative majority were unable to complete their constitutional terms. Lula da Silva in 20037 was the first exception. Still, 2005 was marked by a severe political crisis (the socalled escândalo do mensalão or monthly stipend scandal), which originated in the poor management of the president's legislative coalition and almost led to an impeachment. Note, however, that since the promulgation of the 1988 Constitution, Brazil's coalitional presidencies have been, on average, considerably more stable and effective than their 1946-64 predecessors. This is a consequence of the extensive agenda-setting and lawmaking powers now granted to the executive (Figueiredo and Limongi 1999; Santos 2003).

As for Brazilian political parties, they are a motley crew. While some of them are markedly parochial, clientelistic, and undisciplined, others are nationally oriented, more programmatic, and thoroughly disciplined. In general, left-wing parties—such as the Workers' Party (PT) - belong to the latter group, whereas rightwing parties are almost always found in the former (Mainwaring 1999). Almeida (2004) shows that left-wing parties are the only ones with a real programmatic concern for foreign policy. This feature led us to test the impact of only those parties on Brazil's diplomatic behavior.

A note on the Brazilian military is in order. Since the 1930s, it has been markedly and invariably anticommunist, so its impact on foreign policy was mostly pro-U.S., particularly in the first decades of the Cold War. However, in the 1970s, 
the generals began to diverge from Washington on key strategic issues. In terms of their domestic political power, the armed forces were very influential in the first democratic experience, so much so that they toppled the regime in 1964. In the 1964-85 period they were obviously hegemonic. At the outset of the new democratic regime in 1985, they retained considerable prerogatives and autonomy, with each branch entitled to a cabinet minister plus the president's military chief of staff and the head of the Joint General Staff, both offices with cabinet rank (Stepan 1988). These positions lasted until the creation of a civilian-led Ministry of Defense in 1999. Since then the military's domestic power has waned.

Brazil's foreign policy since 1946 can be described as a permanent quest for autonomy, but with distinct contours for different environments (Rodríguez 2012). Although foreign policy during the Cold War can be characterized as a bid for "autonomy through distance" in regard to foreign powers and regional rivals, in the decade after the fall of the Berlin Wall, the country's diplomacy was distinguished by "autonomy through participation" in international institutions and regional organizations (Fonseca 2004). Yet since Lula came to power in 2003, Brazil's foreign policy has acquired a moderately revisionist tone (Lima 2010).

Autonomy through distance was the diplomatic expression of Brazil's developmentalism, under which the country accepted the demand for alignment with the United States while trying to use it as a bargaining chip for economic advantages. This was the policy that held sway during the 1940s and 1950s. However, in the early 1960s, Brazil began to "qualify" its alignment, even under the staunchly anticommunist military regime. The country agreed to bandwagon with the United States with respect to fundamental values but did not translate that into strategic engagement. The best example of this was the severance of the U.S.-Brazil Military Agreement by Brasília in 1977. In other words, Brazil's foreign policy during the Cold War was a kind of Americanism à la carte.

Right after the end of the Cold War, Brazil shed its arms'-length approach to the global order. Autonomy through participation implied the adherence to international regimes in order to leverage the country's foreign policy leeway. Thus Brasilia tried to shape the international agenda with the values embedded in its diplomatic tradition: multilateralism, legalism, pacifism, and noninterventionism. A telling example of the country's willingness to participate in the shaping of the global order was its return to the UN Security Council in 1988-89 and 1993-94 after a long absence, its presence in several UN peacekeeping operations, and an enhanced dialogue with the European Union (Fonseca 2004, 368-69). However, since the PT came to power in 2003, Brazil's foreign policy has turned into what Vigevani and Cepaluni (2007) label "autonomy through diversification," meaning the adherence to international norms by means of South-South and regional alliances in order to reduce asymmetries with the developed countries, thereby assuming reformist positions toward international institutions and a more assertive diplomatic stance. 


\section{Mexico}

Just like Argentina and Brazil, Mexico features a federal organization and a presidentialist type of government. Unlike both of them, however, it has had regime stability since 1929, when the party now called the Institutional Revolutionary Party (PRI) was founded. No coups of state and no presidential re-elections have occurred since that date, a combination of institutional continuity and personnel renewal infrequent in the Latin American landscape. Moreover, since 1946, the military has been prevented from meddling in politics (Camp 1992), another rare feature south of the Rio Grande.

The PRI ideology has varied widely over time. Plutarco Elías Calles, its founder, was a conservative politician who held presidential office in the 1920s, but the most renowned party leader was center-left, nationalist president Lázaro Cárdenas, who expropriated the foreign oil companies during his 1934-40 term. Overall, 14 PRI presidents governed the country under a hegemonic party system spanning 71 years - and since 1946, all of them were ideologically center or center-right, with the lone exception of Luis Echeverría (1970-76). However, the last two PRI tenures (1988-2000) were marked by relative pluralism in terms of cabinet makeup, as leftof-center ministers came to occupy positions. Eventually, in 2000, the center-right National Action Party (PAN) won the presidential election and stayed in power for the following 12 years.

Mexico's foreign policy has been overdetermined by geography. Its relationship with the United States is unique: it is the only Latin American country to have a common border with the continental hegemon, which has led to traumatic historical events, such as the Texas Revolution (1835-36) and the Mexican-American War (1846-48), in the aftermath of which Mexico lost half its territory. After the 1910 revolution, ousted president Porfirio Díaz is credited to have exclaimed, "Poor Mexico, so far from God and so close to the United States!" referring as much to the anticlerical traits of the new political order as to the threatening proximity of the giant neighbor. Ever since, keeping the United States out of Mexico's domestic affairs has been a constant national goal.

Mexico's foreign policy was imbued with the Estrada Doctrine from the 1930s to the early 2000s. Named after Genaro Estrada, Secretary of Foreign Affairs during the presidency of Pascual Ortiz (1930-32), it states that governments should not judge their counterparts in foreign nations, as such action would imply a violation of sovereignty. This policy stemmed from the principles of nonintervention, peaceful resolution of disputes, and self-determination, much in line with the doctrines developed by foreign ministers Rio Branco (1902-12) in Brazil and Luis María Drago (1902-3) in Argentina, both of which endured throughout the twentieth century. If there is a contrast between Mexico and the other two countries, it resides in the stability of its political regime. The period of PRI hegemony prevented foreign policy guidelines from suffering abrupt changes due to bureaucratic reshuffling or political discontinuities. In the post-Cold War era, however, Mexico began to redefine its foreign policy considerably, pressed by necessity but also taking advan- 
tage of the new geopolitical context (González 2001). As a consequence, the Estrada Doctrine was challenged during the Vicente Fox Administration (2000-2006) and became effectively discontinued under Felipe Calderón (2006-12).

Díaz-Cayeros and Selee (2010) list three "truths" about the current U.S.Mexico relationship: intense interdependence, high complexity, and asymmetry. These truths have led to an unconventional relationship, depicted as "a mixture of foreign and domestic policy, an intermestic relationship ... as the diplomatic agenda is primarily driven by domestic considerations in each country" (Díaz-Cayeros and Selee 2010, 4-5). To disentangle and weigh each dimension is one of the goals of our econometric analysis.

\section{ECONOMETRIC ANALYSIS}

We employed time-series analysis using an OLS model with Newey-West-corrected standard errors to evaluate-separately for each country—the determinants of simple convergence between Argentina, Brazil, and Mexico and the United States in the period 1946-2008. ${ }^{4}$

Table 1 displays four models for Argentina. The first one includes all the independent variables. Cincarg stands for the national capabilities of Argentina; cincusa stands for the national capabilities of the United States; exp is the first-order lag of trade dependence on the United States; left is the cabinet strength of the left and center; mil is the cabinet strength of the military; war1982 is a dummy for the Malvinas/Falklands War in 1982; coldwar is a dummy for the Cold War $(1946-89=1)$ and post-Cold War (1990-2008 = 0) periods; and strength is the political strength of the president ( 1 if the president is the leader of the main party or the head of the army; 0 otherwise). Strength is our solution to tap the president's political strength under both democratic and authoritarian regimes because, unlike Brazil and Mexico, authoritarianism in Argentina always led to the closing down of Congress.

The variables found to be significant in the full model were cincarg, cincusa, exp, left, mil, and war1982. However, cincarg, exp, and mil came with the wrong sign. After pruning down the models, left proved to have a stable and high statistical significance. Note, however, that cincusa is not cincarg. So we calculated the national capabilities ratio between the United States and Argentina. This ratio also proved to have a stable statistical significance in many models. It is reported under the second and third models in table 1 . This variable indicates that the lower the ratio, the less Argentina votes with the United States. But throughout 1946-2008, Argentina did little or nothing to contribute to the lowering of the ratio. Actually, cincarg declined over time. This means that it was not the strengthening of Argentina's national capabilities that led the country to vote less with the United States but the decline in U.S. power.

In addition, the negative sign on left indicates that the greater the cabinet strength of the center or left, the less Argentina voted with the United States (note that the cabinet strength of the right is not included in the models because it is collinear with left). This variable is considerably significant (at the 0.05 level), and shows the relevance of domestic politics in shaping Argentina's foreign policy. 
Table 1. Determinants of the Convergence Between Argentina and the United States in the UN, 1946-2008

\begin{tabular}{|c|c|c|c|c|}
\hline Dependent variable & $\begin{array}{c}1 \\
\text { conv }\end{array}$ & $\begin{array}{c}2 \\
\text { conv }\end{array}$ & $\begin{array}{c}3 \\
\text { conv }\end{array}$ & $\begin{array}{c}4 \\
\text { Lijphart }\end{array}$ \\
\hline cincarg & $\begin{array}{l}118.1^{*} \\
(63.67)\end{array}$ & $\begin{array}{l}177.8^{* * *} \\
(32.33)\end{array}$ & & \\
\hline cincusa & $\begin{array}{c}2.150 \\
(1.421)\end{array}$ & & & \\
\hline $\exp (\operatorname{lag})$ & $\begin{array}{c}-1.150 \\
(0.762)\end{array}$ & $\begin{array}{c}-1.049 \\
(0.670)\end{array}$ & & \\
\hline left & $\begin{array}{r}-0.124^{* *} \\
(0.0562)\end{array}$ & $\begin{array}{r}-0.130^{* *} \\
(0.0544)\end{array}$ & $\begin{array}{c}-0.143^{* *} \\
(0.0703)\end{array}$ & $\begin{array}{r}-0.174^{* *} \\
(0.0675)\end{array}$ \\
\hline mil & $\begin{array}{c}-0.239^{* *} \\
(0.0973)\end{array}$ & $\begin{array}{r}-0.230^{* *} \\
(0.0969)\end{array}$ & & \\
\hline war1982 & $\begin{array}{c}-0.289^{* * *} \\
(0.0782)\end{array}$ & $\begin{array}{c}-0.285^{* * *} \\
(0.0679)\end{array}$ & & \\
\hline coldwar & $\begin{array}{c}0.00525 \\
(0.0470)\end{array}$ & $\begin{array}{c}0.00839 \\
(0.0452)\end{array}$ & & \\
\hline strength & $\begin{array}{c}0.0191 \\
(0.0444)\end{array}$ & $\begin{array}{c}0.0149 \\
(0.0430)\end{array}$ & & \\
\hline cincratio & & $\begin{array}{c}0.0156^{*} \\
(0.00863)\end{array}$ & $\begin{array}{c}0.0284^{* * *} \\
(0.00567)\end{array}$ & $\begin{array}{l}0.0263^{* * *} \\
(0.0043)\end{array}$ \\
\hline _cons & $\begin{array}{c}-0.527^{* *} \\
(0.218)\end{array}$ & $\begin{array}{c}-0.964^{* * *} \\
(0.180)\end{array}$ & $\begin{array}{c}-0.368^{* *} \\
(0.139)\end{array}$ & $\begin{array}{c}-0.1268 \\
(0.1108)\end{array}$ \\
\hline $\mathrm{N}$ & 63 & 63 & 63 & 63 \\
\hline
\end{tabular}

${ }^{*} \mathrm{p}<0.1,{ }^{* *} \mathrm{p}<0.05,{ }^{* * *} \mathrm{p}<0.01$.

Standard errors in parentheses.

Note: Time-series analysis using an OLS model with Newey-West-corrected standard errors.

To check the robustness of our findings on Argentina, under the fourth model we ran the third model using Lijphart's Index of Agreement as the operational indicator of the dependent variable instead of simple convergence. Note that the Index of Agreement tends to produce higher levels of convergence than simple convergence. Yet our main findings on Argentina hold under Lijphart's Index of Agreement, a good sign that our tests are robust. ${ }^{5}$

Table 2 exhibits four models for Brazil. Here again, model 1 includes all the independent variables: cincbra, the national capabilities of Brazil; cincusa, the national capabilities of the United States; exp, the first-order lag of trade dependence on the United States; presparty, the legislative size of the president's party; ideopres, the ideology of the president (per Coppedge 1997); cableft, the cabinet strength of the left; legleft, the legislative size of left-wing parties; mil, the cabinet strength of the 
Table 2. Determinants of the Convergence Between Brazil and the United States in the UN, 1946-2008

\begin{tabular}{|c|c|c|c|c|}
\hline Dependent variable & $\begin{array}{c}1 \\
\text { conv }\end{array}$ & $\begin{array}{c}2 \\
\text { conv }\end{array}$ & $\begin{array}{c}3 \\
\text { conv }\end{array}$ & $\begin{array}{c}4 \\
\text { Lijphart }\end{array}$ \\
\hline cincbra & $\begin{array}{c}-47.70^{* * *} \\
(10.43)\end{array}$ & & $\begin{array}{c}-46.98^{* * *} \\
-3.133\end{array}$ & $\begin{array}{c}-43.33^{* * *} \\
(2.762)\end{array}$ \\
\hline cincusa & $\begin{array}{c}-1.074^{*} \\
(0.609)\end{array}$ & & & \\
\hline $\exp ($ lag $)$ & $\begin{array}{l}0.876^{* *} \\
(0.392)\end{array}$ & $\begin{array}{l}1.542^{* * *} \\
(0.324)\end{array}$ & & \\
\hline presparty & $\begin{array}{c}0.226^{*} \\
(0.120)\end{array}$ & $\begin{array}{c}0.0190 \\
(0.146)\end{array}$ & & \\
\hline ideopres & $\begin{array}{c}-0.213^{*} \\
(0.112)\end{array}$ & $\begin{array}{c}0.0798 \\
(0.107)\end{array}$ & & \\
\hline cableft & $\begin{array}{c}-0.208^{* *} \\
(0.101)\end{array}$ & $\begin{array}{c}-0.0272 \\
(0.116)\end{array}$ & $\begin{array}{c}-0.0943^{*} \\
(0.0509)\end{array}$ & $\begin{array}{c}-0.2064^{* * *} \\
(0.0532)\end{array}$ \\
\hline legleft & $\begin{array}{c}0.181 \\
(0.277)\end{array}$ & $\begin{array}{c}-0.425^{*} \\
(0.230)\end{array}$ & & \\
\hline mil & $\begin{array}{l}0.506^{* *} \\
(0.251)\end{array}$ & & & \\
\hline coldwar & $\begin{array}{c}-0.221^{* *} \\
(0.0916)\end{array}$ & $\begin{array}{c}-0.00275 \\
(0.0740)\end{array}$ & & \\
\hline cincratio & & $\begin{array}{c}0.00645 \\
(0.00630)\end{array}$ & & \\
\hline _cons & $\begin{array}{l}1.242^{* * *} \\
(0.296)\end{array}$ & $\begin{array}{c}-0.0511 \\
(0.124)\end{array}$ & $\begin{array}{l}1.365^{* * *} \\
(0.0616)\end{array}$ & $\begin{array}{c}1.442^{* * *} \\
(0.0573)\end{array}$ \\
\hline $\mathrm{N}$ & 63 & 63 & 63 & 63 \\
\hline
\end{tabular}

${ }^{*} \mathrm{p}<0.1,{ }^{* *} \mathrm{p}<0.05,{ }^{* * *} \mathrm{p}<0.01$.

Standard errors in parentheses.

Note: Time-series analysis using an OLS model with Newey-West-corrected standard errors.

military; and coldwar, a dummy for the Cold War $(1946-89=1)$ and post-Cold War $(1990-2008=0)$ periods.

Because of multipartyism and coalitional presidentialism, there is no perfect match between the cabinet makeup and its supporting legislative majority (unlike Argentina and in Mexico in 1946-97, as we will see). This is why we had to include president-centered, cabinet-centered, and legislative-centered variables. That is to say, for Brazil we need to have distinct measures for the ideology and political strength of the president, the cabinet, and legislative parties. Presparty is based on the finding that the larger the president's party, the stronger his or her position in relation to the coalition allies and the more stable the government (Amorim Neto 2006; Power 2010). 
The variables found to be significant in the first, full model were cincbra, exp, mil, and coldwar, suggesting a complex mix of foreign policy determinants. However, after pruning down the models, only cincbra proved to have stable statistical significance. While $\exp$ was found significant in the first two models, it lost significance as the right-hand side of the equation was pruned down. That is to say, exp proved to be an unstable variable, lacking robustness. The best model we obtained was the third one, which includes cincbra, and cableft on the right-hand side of the regression equation. The fourth model—which uses Lijphart's Index of Agreement as the dependent variable - indicates that the coefficients under the third model are robust. Our findings show that the neorealist variable is the most relevant factor affecting Brazil's foreign policy.

While cableft indicates that domestic politics plays a role in shaping Brazil's international behavior, it is a weaker role than that played by the country's national capabilities. ${ }^{6}$ The significance of coldwar under model 1 further suggests the relevance of systemic variables in shaping Brazil's international alignment patterns. The negative sign on coldwar shows that contrary to our third proposition, Brazil drifted away from the United States during the Cold War. Conversely, after the Cold War, Brasília rehearsed a rapprochement with Washington. All our findings hold under Lijphart's Index of Agreement. ${ }^{7}$

Table 3 displays four models for Mexico. The independent variables, all included in the first model, are cincmex, the national capabilities of Mexico; cincusa, the national capabilities of the United States; exp, the first-order lag of trade dependence on the United States; left, the cabinet strength of the left. Unigovt is a dummy that equals 1 if the president's party controls Congress, 0 otherwise; ideopres is the ideology of the president (per Coppedge 1997); mil, the cabinet strength of the military; coldwar, a dummy for the Cold War $(1946-89=1)$ and post-Cold War $(1990-2008=0)$ periods.

Because of the decades-long dominance of the PRI, we had to include unigovt on the right-hand side of the equation. This variable taps the legislative situation of the president and his party. Unlike Brazil but like Argentina, coalitions are the not the norm in Mexico. So if the president's party does not command a legislative majority, the president will be in the minority by definition (Casar 2002; Craig and Cornelius 1995; Weldon 1997). There was unified government (a situation in which the president's party controls both houses of Congress) from 1946 to 1997. In 1997 the PRI lost its legislative majority, ushering in an era of divided government that has not yet ended.

The only variable found to be significant in the full model was cincmex. After pruning down the models, only cincmex proved to have stable statistical significance. The best model (in terms of the significance and stability of the coefficients) we obtained was the third one, which includes only cincmex. ${ }^{8}$ Thus, our findings show that the neorealist variable is the crucial factor affecting Mexico's foreign policy. Closer to the conclusions reached by Mares (1988b) rather than Sotomayor Velázquez (2009), domestic politics seems to play no significant role in determining this country's international behavior in the long run. The finding on cincmex holds under Lijphart's Index of Agreement. ${ }^{9}$ 
Table 3. Determinants of the Convergence Between Mexico and the United States in the UN, 1946-2008

\begin{tabular}{|c|c|c|c|c|}
\hline Dependent variable & $\begin{array}{c}1 \\
\text { conv }\end{array}$ & $\begin{array}{c}2 \\
\text { conv }\end{array}$ & $\begin{array}{c}3 \\
\text { conv }\end{array}$ & $\begin{array}{c}4 \\
\text { Lijphart }\end{array}$ \\
\hline cincmex & $\begin{array}{c}-46.61^{*} \\
(23.34)\end{array}$ & & $\begin{array}{c}-70.77^{* * *} \\
(6.926)\end{array}$ & $\begin{array}{c}-71.726^{* * *} \\
(6.628)\end{array}$ \\
\hline cincusa & $\begin{array}{c}1.079 \\
(0.962)\end{array}$ & & & \\
\hline $\exp (\mathrm{lag})$ & $\begin{array}{c}-0.359 \\
(0.395)\end{array}$ & & & \\
\hline unigovt & $\begin{array}{c}0.00256 \\
(0.0944)\end{array}$ & & & \\
\hline ideopres & $\begin{array}{c}-0.0476 \\
(0.0323)\end{array}$ & & & \\
\hline left & $\begin{array}{c}-0.0219 \\
(0.0955)\end{array}$ & $\begin{array}{c}0.0691 \\
(0.0580)\end{array}$ & & \\
\hline mil & $\begin{array}{c}0.341 \\
(0.366)\end{array}$ & & & \\
\hline coldwar & $\begin{array}{c}-0.0729 \\
(0.0735)\end{array}$ & & & \\
\hline cincratio & & $\begin{array}{c}0.0120^{* * *} \\
(0.00177)\end{array}$ & & \\
\hline _cons & $\begin{array}{c}1.030^{* *} \\
(0.410)\end{array}$ & $\begin{array}{c}0.0558 \\
(0.0385)\end{array}$ & $\begin{array}{l}1.054^{* * *} \\
(0.0730)\end{array}$ & $\begin{array}{c}1.202^{* * *} \\
(0.0677)\end{array}$ \\
\hline $\mathrm{N}$ & 63 & 63 & 63 & 63 \\
\hline
\end{tabular}

${ }^{*} \mathrm{p}<0.1,{ }^{* *} \mathrm{p}<0.05,{ }^{* * *} \mathrm{p}<0.01$.

Standard errors in parentheses.

Note: Time-series analysis using an OLS model with Newey-West-corrected standard errors.

A note is in order on the absence of statistical significance of strength in Argentina, presparty in Brazil, and unigovt in Mexico. These findings indicate that our sixth proposition (the magnitude of the president's political support has neutral effects as a determinant of foreign policy) is correct. This does not mean that the president's political situation is irrelevant in understanding these countries' foreign policies, as Keller (2012) has shown. It means that it is only relevant in the short term, something that our tests are unlikely to capture but qualitative research designs can grasp-and they have, as in the case of interpresidential dynamics in Mercosur (Malamud 2005).

Finally, we need to explain why the dummy capturing the effect of the Cold War failed to have a significant effect and, in Brazil and Mexico, came with the wrong sign. In the cases of Argentina and Brazil, this may be because the democratic regimes established in the early 1980s did not face any meaningful left-wing chal- 
lengers-unlike previous democratic periods. Therefore, in these countries, the Cold War fizzled out as the military dictatorships receded, a few years before the Berlin Wall fell. Meanwhile, in Mexico, a pro-Soviet government was always out of the question. ${ }^{10}$

\section{Conclusions}

This article has postulated that given the distinct national capabilities and positioning in the international system of Argentina and Mexico, the latter would be likely to follow a path similar to Brazil's while the former's foreign policy would be more sensitive to domestic changes. Our tests confirmed these propositions. Mexico's foreign policy is determined mostly by its national capabilities. Its CINC almost doubled over the 63-year period covered in our analysis, just like Brazil's, and this increase coincides with a diverging voting pattern in relation to the United States. Domestic variables have shown no significant effect. Figuratively, it can be said that Mexico is a very Waltzian state.

In the case of Argentina, the CINC alone is not a good predictor of voting behavior, but its ratio relative to the CINC of the United States is significant. Yet as we have noted, throughout 1946-2008 Argentina did little or nothing to help lower the ratio, so the value of this finding should not be exaggerated.

The liberal hypothesis is also disconfirmed, as trade dependence on the United States does not covariate with voting convergence. This is consistent with the findings of Paz (2012), who additionally shows that Argentine behavior at the UN is not correlated with trade dependence on China either. The most robust predictor of Argentina's foreign alignment is the cabinet strength of the center-left-simply defined as non-right, and therefore encompassing most of the civilian administrations. In short, democracy matters. Given that Argentina has mostly featured singleparty governments and that military presidents have largely run the government with a tight hand, the ideological orientation of the cabinet reflects almost perfectly the president's ideological leaning.

Domestic factors carry the day in explaining Argentina's foreign strategy, which helps us to understand why this country has displayed a more erratic international behavior than both Brazil and Mexico. This finding does not disprove realist theories, since their "acid test ... is not whether states conform to realpolitik principles but whether those states that do not conform are worse off than those that do" (Feaver et al. 2000, 165). Judging by indicators such as relative material capabilities or international reputation, Argentina seems to have paid its price for reneging on the tenets of realism.

We have shown the primacy of systemic factors over domestic factors, as well as of high politics (i.e., national capabilities) over low politics (i.e., trade interdependence), in determining Brazil's and Mexico's degree of convergence with the United States when voting in the UN General Assembly. Certainly, the degree of political support and personal activism of the chief executives has affected the way ideological preferences have interacted with systemic pressures. For example, the 
presence of left-wing ministers in the cabinet has shown a modest statistical effect in Brazil, though we have found no such effect for Mexico. This could be because Mexico has not had a leftist government since the end of the Cold War. If the left comes to power in the near future, the results might change.

In line with realist arguments, our findings suggest that the parameters of Brazilian and Mexican foreign policy were set by their relative material power. However, following neoclassical realism, we have also looked for the transmission belts that link material capabilities to foreign policy behavior (Rose 1998). We found that domestic factors, such as the political power of the military, the degree of legislative support for the president, and the ideological makeup of the cabinet, show some effects under certain conditions, depending on country and context.

On the other hand, Argentina exhibited a behavior less predictable on the basis of systemic factors, thus requiring a deeper analysis of the domestic variables. The conclusion is that, in this country, agency appears more influential over voting alignment than in the other cases. The irony is that this apparent gain in autonomy has not been accompanied by an increase in national capabilities or international influence, as Argentina has declined (while Brazil and Mexico have ascended) during the period under analysis.

For the most part, our findings are consistent with Gómez-Mera's conclusions on Mercosur $(2013,3)$; she verifies that "the impact of ... systemic forces on regional outcomes ... has been crucially mediated by domestic political dynamics in the bloc's two main partners, Argentina and Brazil." This underlines the validity of a neoclassical realist approach to the study of Latin American foreign policies.

As we have seen, the curves describing Argentina's, Brazil's, and Mexico's voting convergence with the United States are remarkably similar, all of them displaying a steep downward trend. Yet the same effect proved to have different determinants. This should not surprise us. After all, the social world is characterized by equifinality and causal heterogeneity. One of the contributions of this article is to pin down the shape of such heterogeneity in the case of Latin American foreign policies. Only with country-specific tests could we do so.

Although this research relies on country-specific tests and measures to check the impact of systemic and domestic variables on voting convergence, our approach can be extended to other Latin American countries and issue areas-as some recent works promise (Amorim Neto 2011; Merke and Pauselli 2014; Mourón and Urdinez 2014; Schenoni 2012; Vigevani and Ramanzini 2011). If data on national capabilities and trade dependence are easy to find, the bulging literature on comparative presidentialism is an excellent source for country-specific domestic variables.

One final variable is omitted from our tests: diplomatic inertia. Following Allison (1971), it is to be expected that the more professionalized the diplomatic corps, the more incremental the changes in foreign policy and the less influential the domestic factors. Greater diplomatic professionalization means two things. First, it allows the foreign ministry to impose its views and doctrines more easily on the chief executive, thereby generating greater inertia or intertemporal consistency in international behavior, ceteris paribus. Second, it allows the foreign ministry to better con- 
test the policy preferences of other bureaucratic and political players, thereby downplaying the role of other domestic factors in shaping foreign policy. To verify those propositions, future research should try to quantify the degree of diplomatic professionalization in Argentina, Brazil, and Mexico over the 63 years analyzed in this paper. A daunting task awaits us. ${ }^{11}$

\section{Notes}

The authors thank Roderic Ai Camp, Alain De Remes, Todd Eisenstadt, Cecilia Martínez-Gallardo, and Antonio Ortiz-Mena for their expert advice on the ideology of Mexican parties, presidents, and cabinet members; Marcelo Camerlo and Miguel De Luca for their assistance with the Argentine cabinets; Pablo Gerchunoff and David Scott Palmer for their help to find historical databases; Christian Arnold, Nathan Canen, Júlio C. Rodríguez, and Luis Schenoni for their comments on earlier versions; and five anonymous reviewers for their criticism and suggestions. Igor Acacio, Mariana Carvalho, Carlos Coelho, Karina Rodrigues, and Saulo Said provided outstanding research assistance.

1. We accept that there may be a tipping point before which national capability gaps create a dissonance of interest. Beyond that point, though, the closer the national capabilities, the more natural the alignment between countries - due to shared class and capital interests. Unlike Japan or the European powers, the Latin American states have not reached that point yet. We thank an anonymous reviewer for pointing out this issue.

2. This section draws heavily on Amorim Neto 2011.

3. This is a five-year moving average of each country's exports to the United States as a percentage of total exports. In the econometric tests we use the first-order lag of this indicator to avoid endogeneity.

4. Note that Amorim Neto (2011) uses a Tobit model to identify the determinants of Brazil's diplomatic convergence with the United States. We prefer the Newey-West model because its variance estimator corrects for heteroskedasticity (nonconstant variance) and temporal (auto)correlations in the variables. Since this is likely to be a concern in our time-series analysis, it is appropriate that we incorporate such corrections in our inference. Therefore, when we calculate test statistics, we adopt an estimator for the variance that takes into account those time-series problems. Indeed, normality and homoskedasticity are assumed by the Tobit econometric technique, and are essential for the latter. Those assumptions seem unlikely to hold under our time-series data.

5. To further check the robustness of our findings on Argentina, we included a measure of democracy in the models (not reported here). The scales of Polity IV were used as our operational indicator. Interestingly enough, democracy was found significant and came with a negative sign (which means that higher degrees of democracy are associated with lower diplomatic convergence with the United States). However, the inclusion of this variable eliminated the significance of left and slightly reduced the significance of cincratio. In fact, under a model only with cincratio and Polity on the right-hand side of the regression equation, the latter is the most significant independent variable. This corroborates our finding that in Argentina, domestic factors are the most relevant determinants of foreign policy.

6. In tests on Brazil not reported here, we included the Polity IV measure of democracy on the right-hand side of the regression equations. This measure was never found significant.

7. For Brazil, we also ran models including an interactive term in model 3. We tested the impact of cincbra $^{*}$ cableft, on the assumption that a country with greater national capabilities and a stronger left will vote less with the United States on UN motions. The interactive term was 
found significant and came with the right sign (negative). However, its level of significance was close to 10 percent, not very high, and the same level found for cableft under model 3. Moreover, under the interactive model, cableft came with a positive sign. This means that the effect of this variable on diplomatic convergence comes from the observations with the highest values of cincbra. In short, the interactive term does not change our original findings. As there is no palpable gain in using it, we prefer to stick to the more parsimonious model, the linear one.

8. In tests on Mexico not reported here, we checked the impact of the Polity IV measure of democracy on diplomatic convergence with the United States. As occurred with the tests on Brazil, this measure was never found significant.

9. Ortiz-Mena (2008) has also found that Mexico's trade dependence on the United States does not affect Mexico's votes on UN motions.

10. We ran models including an alternative measure of asymmetric interdependence in relation to Washington: U.S. direct investment. As with trade dependence, we calculated a five-year moving average of U.S. direct investment as a percent of GDP in Argentina, Brazil, and Mexico. We also used the first-order lag of this indicator to avoid endogeneity. Our source for U.S. direct investment was the Bureau of Economic Analysis (www.bea.gov/international/dilusdbal.htm). Our data show that the trend relating to U.S. investment is clearly upward for the three countries in 1966-2008 (no data were available for 1946-65). This is precisely the opposite trend in relation to diplomatic convergence with the United States. It is therefore no wonder that in all tests with the three countries, U.S. direct investment came with the wrong sign (negative). In some tests the coefficient on U.S. direct investment was even significant. That is, the higher the U.S. direct investment, the lower the diplomatic convergence. As this goes totally against the grain, we hang on to exports to the United States as the best measure of asymmetric interdependence available.

11. Amorim Neto (2011) includes the first-order lag of diplomatic convergence on the right-hand side of his regression equations as an indirect measure of the impact of the foreign ministry on diplomatic convergence (on the assumption that the stronger the ministry, the larger the diplomatic inertia). While this indirect measure is not wrong in the case of Brazil, it is a controversial solution. Therefore, we prefer to develop direct measures of the strength of foreign ministries in future research.

\section{REFERENCES}

Abranches, Sérgio H. H. de. 1988. Presidencialismo de coalizão: o dilema institucional brasileiro. Dados 31, 1: 5-38.

Allison, Graham. 1971. Essence of Decision: Explaining the Cuban Missile Crisis. 1st ed. Little Brown.

Almeida, Paulo Roberto de. 2004. Relaçóes internacionais e política externa do Brasil. Porto Alegre: Universidade Federal do Rio Grande do Sul.

Amorim Neto, Octavio. 2006. Presidencialismo e governabilidade nas Américas. Rio de Janeiro: Fundação Getulio Vargas.

- 2011. De Dutra a Lula: a condução e os determinantes da política externa brasileira. Rio de Janeiro: Campus.

Aparicio Cabrera, Abraham. 2011. Series estadísticas de la economía mexicana en el siglo XX. Economía Informa 369 (July-August): 63-85.

Brazil. Ministry of Development, Industry and Foreign Trade. n.d. 200 anos do comércio exterior brasileiro. Brasília. http://mdic.gov.br//sitio/interna/interna.php?area=5\&menu= $2041 \&$ refr $=608$ 
AliceWeb2. Sistema de análise das informaçôes de comércio exterior. http://aliceweb2.mdic.gov.br.

Camp, Roderic Ai. 1992. Generals in the Palacio: The Military in Modern Mexico. Oxford: Oxford University Press.

2011. Mexican Political Biographies, 1939-2009. 4th ed. Austin: University of Texas Press.

Casar, Maria Amparo. 2002. Executive-Legislative Relations: The Case of Mexico (19461997). In Legislative Politics in Latin America, ed. Scott Morgenstern and Benito Nacif. New York: Cambridge University Press. 114-44.

Catterberg, Edgardo, and María Braun. 1989. Izquierda y derecha en la opinión pública argentina. Critica y Utopia 18: 63-79.

Coppedge, Michael. 1997. A Classification of Latin American Political Parties. Kellogg Institute Working Paper 244. Notre Dame: University of Notre Dame.

Covarrubias, Ana. 2003. Mexico: The Challenges of a Latin American Power in the U.S. Backyard. In Latin American and Caribbean Foreign Policy, ed. Frank O. Mora and Jeanne A. K. Hey. New York: Rowman and Littlefield. 13-30.

Craig, Ann L., and Wayne A. Cornelius. 1995. Houses Divided: Parties and Political Reform in Mexico. In Building Democratic Institutions: Party Systems in Latin America, ed. Scott Mainwaring and Timothy R. Scully. Stanford: Stanford University Press. 249-97.

Díaz-Cayeros, Alberto, and Andrew Selee. 2010. Mexico and the United States: The Possibilities of Partnership. Working Paper 10-01. San Diego: Center for U.S.-Mexican Studies, University of California.

Dixon, William J. 1981. The Emerging Image of U.N. Politics. World Politics 34, 1: 47-61. Escudé, Carlos, and Andrés Cisneros. 2000. Historia general de las relaciones exteriores de la República Argentina. Vol. 15. Buenos Aires: Grupo Editor Latinoamericano.

Feaver, Peter D., Gunther Hellmann, Randall Schweller, Jeffrey W. Taliaferro, William Wohlforth, Jeffrey W. Legro, and Andrew Moravcsik. 2000. Brother, Can You Spare a Paradigm? (Or, Was Anybody Ever a Realist?). International Security 25, 1: 165-93.

Figueiredo, Argelina C. 2008. Government Coalitions in Brazilian Democracy. Brazilian Political Science Review 1, 2: 182-216.

Figueiredo, Argelina C., and Fernando Limongi. 1999. Executivo e legislativo na nova ordem constitucional. Rio de Janeiro: Fundação Getúlio Vargas.

Fonseca, Gelson, Jr. 2004. A legitimidade e outras questôes internacionais. São Paulo: Paz e Terra.

Gardini, Gian Luca, and Peter Lambert, eds. 2011. Latin American Foreign Policies: Between Ideology and Pragmatism. New York: Palgrave Macmillan.

Gómez-Mera, Laura. 2013. Power and Regionalism in Latin America: The Politics of MERCOSUR. Notre Dame: University of Notre Dame Press.

González, Guadalupe. 2001. Foreign Policy Strategies in a Globalized World: The Case of Mexico. In Latin America in the New International System, ed. Joseph S. Tulchin and Ralph H. Espach. Boulder: Lynne Rienner. 141-82.

Instituto Brasileiro de Geográfica e Estadistica (IBGE). n.d. Anuário estatístico do Brasil. Rio de Janeiro.

Keller, Renata. 2012. A Foreign Policy for Domestic Consumption: Mexico's Lukewarm Defense of Castro, 1959-1969. Latin American Research Review 47, 2: 100-119.

Kennedy, Paul. 2006. The Parliament of Man: The Past, Present, and Future of the United Nations. New York: Random House.

Lampreia, Luiz Felipe. 2010. O Brasile os ventos do mundo: memórias de cinco décadas de cena internacional. Rio de Janeiro: Objetiva. 
Lanús, Juan Archibaldo. 1986. De Chapultepec al Beagle: politica exterior argentina, 19451980. Buenos Aires: Hyspamérica.

Lijphart, Arend. 1963. The Analysis of Bloc Voting in the General Assembly: A Critique and a Proposal. American Political Science Review 57, 4: 902-17.

Lima, Maria Regina Soares de. 2010. Brasil e pólos emergentes do poder mundial: Rússia, Índia, China e África do Sul. In O Brasil e os demais BRICS: comércio e politica, ed. Renato Baumann. Brasília: CEPAL/IPEA. 155-79.

Lima, Maria Regina Soares de, and Mónica Hirst. 2006. Brazil as an Intermediate State and Regional Power: Action, Choice and Responsibilities. International Affairs 82, 1: 21-40. Lobell, Steven E., Jeffrey Taliaferro, and Norrin Ripsman, eds. 2009. Neoclassical Realism, the State and Foreign Policy. Cambridge: Cambridge University Press.

Mainwaring, Scott. 1999. Rethinking Party Systems in the Third Wave of Democratization: The Case of Brazil. Stanford: Stanford University Press.

Malamud, Andrés. 2005. Presidential Diplomacy and the Institutional Underpinnings of Mercosur: An Empirical Examination. Latin American Research Review 40, 1: 138-64.

- 2011. Argentine Foreign Policy Under the Kirchners: Ideological, Pragmatic, or Simply Peronist? In Gardini and Lambert 2011. 87-102.

Mares, David R. 1988a. Middle Powers Under Regional Hegemony: To Challenge or Acquiesce in Hegemonic Enforcement. International Studies Quarterly 32, 4: 453-71.

. 1988b. Mexico's Foreign Policy as a Middle Power: The Nicaragua Connection, 1884-1986. Latin American Research Review 23, 3: 81-107.

Margheritis, Ana. 2010. Argentina's Foreign Policy: Domestic Politics and Democracy Promotion in the Americas. Boulder: Lynne Rienner.

Marín-Bosch, Miguel. 1998. Votes in the UN General Assembly. The Hague: Kluwer Law International.

Merke, Federico, and Gino Pauselli. 2014. El voto latinoamericano en Naciones Unidas 1975-2012: factores de convergencia con los Estados Unidos. Paper presented at the Seminario de Ciencias Sociales en la Universidad De San Andrés, Victoria (Buenos Aires), April 3.

Molinelli, N. Guillermo, M. Valeria Palanza, and Gisela Sin. 1999. Congreso, presidencia y justicia en Argentina: materiales para su estudio. Buenos Aires: CEDI/Fundación Gobierno y Sociedad/Temas Grupo.

Mourón, Fernando, and Francisco Urdinez. 2014. A Comparative Analysis of Brazil's Foreign Policy Drivers Towards the USA: Comment on Amorim Neto (2011). Brazilian Political Science Review 8, 2: 92-113.

Ortiz-Mena, Antonio. 2008. El Tratado de Libre Comércio y la política exterior de México: lo esperado y lo acontecido. In Temas de politica exterior, ed. Ana Covarrubias. Mexico City: El Colégio de México. 125-59.

Paz, Gonzalo S. 2012. Are Latin American Economies and Foreign Policies Diversifying? The Impact of Rising China and U.S. Reactions. Ph.D. diss., George Washington University.

Polity IV Project. Dataset coding authority characteristics of states in the world system. Vienna, VA: Center for Systemic Peace. www.systemicpeace.org/polityproject.html

Power, Timothy J. 2010. Optimism, Pessimism, and Coalitional Presidentialism: Debating the Institutional Design of Brazilian Democracy. Bulletin of Latin American Research 29, 1: 18-33.

Quijano Torres, Manuel. 2012. 200 años de administración pública en México. Vol. 3: Los gabinetes en México, 1821-2012. Mexico City: Instituto Nacional de Administración Pública. 
Rodríguez, Júlio César Cossio. 2012. Chacal ou cordeiro? O Brasil frente aos desafios e oportunidades do sistema internacional. Revista Brasileira de Politica Internacional 55, 2: 7089.

Rose, Gideon. 1998. Neoclassical Realism and Theories of Foreign Policy. World Politics 51, 1: 144-72.

Russell, Roberto, and Juan Gabriel Tokatlian. 2006. Will Foreign Allies Help? Argentina's Relations with Brazil and the United States. In Broken Promises? The Argentine Crisis and Argentine Democracy, ed. Edward Epstein and David Pion-Berlin. Lanham: Rowman and Littlefield. 245-69.

Santos, Fabiano. 2003. O poder legislativo no presidencialismo de coalizão. Belo Horizonte: Universidade Federal de Minas Gerais.

Schenoni, Luis. 2012. Los determinantes sistémicos de la política externa brasileña en el contexto de América Latina. Paper presented at the 4th Uruguayan Congress of Political Science (AUCiP), Montevideo, November 14-16.

Schweller, Randall L. 2004. Unanswered Threats: A Neoclassical Realist Theory of Underbalancing. International Security 29, 2: 159-201.

Selcher, Wayne. 1978. Brazil's Multilateral Relations: Between First and Third Worlds. Boulder: Westview Press.

Singer, J. David, Stuart Bremer, and John Stuckey. 1972. Capability Distribution, Uncertainty, and Major Power War, 1820-1965. In Peace, War, and Numbers, ed. Bruce Russett. Beverly Hills: Sage. 19-48.

Sotomayor Velázquez, Arturo C. 2009. Different Paths and Divergent Policies in the UN Security System: Brazil and Mexico in Comparative Perspective. International Peacekeeping 16, 3: 364-78.

Stepan, Alfred. 1988. Rethinking Military Politics: Brazil and the Southern Cone. Princeton: Princeton University Press.

Thacker, Strom C. 1999. The High Politics of IMF Lending. World Politics 52, 1: 38-75.

Tomlin, Brian W. 1985. Measurement Validation: Lessons from the Use and Misuse of UN General Assembly Roll-Call Votes. International Organization 39, 4: 189-206.

U.S. Census Bureau. 1940-2012. Exports, Imports, and Merchandise Trade Balance, by Country-Statistical Abstract of the United States. Washington, DC: U.S. Census Bureau. http://www.census.gov.

Vigevani, Tullo, and Gabriel Cepaluni. 2007. Lula's Foreign Policy and the Quest for Autonomy Through Diversification. Third World Quarterly 28, 7: 1309-26.

Vigevani, Tullo, and Haroldo Ramanzini Júnior. 2011. The Impact of Domestic Politics and International Changes on the Brazilian Perception of Regional Integration. Latin American Politics and Society 53, 1 (Spring): 125-55.

Voeten, Erik. 2000. Clashes in the Assembly. International Organization 54, 2: 185-215.

Voeten, Erik, and Adis Merdzanovic. 2008. United Nations General Assembly Voting Data. Database. hdl:1902.1/12379 UNF:3:Hpf6qOkDdzzvXF9m66yLTg==.

Weldon, Jeffrey. 1997. The Political Sources of Presidencialismo in Mexico. In Presidentialism and Democracy in Latin America, ed. Scott Mainwaring and Matthew Soberg Shugart. Cambridge: Cambridge University Press. 225-58.

Zakaria, Fareed. 1998. From Wealth to Power: The Unusual Origins of America's World Role. Princeton: Princeton University Press. 